Article

\title{
Phytochemical Constituents, Antioxidant, Cytotoxic, and Antimicrobial Activities of the Ethanolic Extract of Mexican Brown Propolis
}

\author{
J. Fausto Rivero-Cruz ${ }^{1, *(\mathbb{D}}$, Jessica Granados-Pineda ${ }^{1}{ }^{\mathbb{D}}$, José Pedraza-Chaverri $\left.{ }^{1}{ }^{(}\right)$,

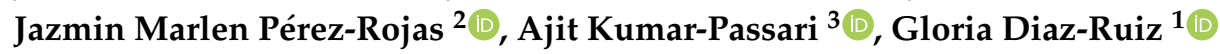 \\ and Blanca Estela Rivero-Cruz ${ }^{1}$ \\ 1 Facultad de Química, Universidad Nacional Autónoma de México, Ciudad Universitaria, \\ Ciudad de México 04510, Mexico; jessygpin@hotmail.com (J.G.-P.); pedraza@unam.mx (J.P.-C.); \\ gloriadr@unam.mx (G.D.-R.); blancariv@unam.mx (B.E.R.-C.) \\ 2 División de Investigación Básica, Instituto Nacional de Cancerología, Av. San Fernando 22, \\ Apartado Postal 22026, Tlalpan 14000, Mexico; jazminmarlen@gmail.com \\ 3 Instituto de Investigaciones Biomédicas, Universidad Nacional Autónoma de México, Ciudad Universitaria, \\ Ciudad de México 04510, Mexico; ajit.passari22@iibiomedicas.unam.mx \\ * Correspondence: joserc@unam.mx; Tel.: +52-55-5622-5281
}

Received: 30 November 2019; Accepted: 4 January 2020; Published: 13 January 2020

\begin{abstract}
Propolis is a complex mixture of natural sticky and resinous components produced by honeybees from living plant exudates. Globally, research has been dedicated to studying the biological properties and chemical composition of propolis from various geographical and climatic regions. However, the chemical data and biological properties of Mexican brown propolis are scant. The antioxidant activity of the ethanolic extract of propolis (EEP) sample collected in México and the isolated compounds is described. Cytotoxic activity was evaluated in a central nervous system and cervical cancer cell lines. Cytotoxicity of EEP was evaluated in a C6 cell line and cervical cancer (HeLa, $\mathrm{SiHa}$, and CasKi) measured by the 3-(3,5-dimethylthiazol-2-yl)2,5-diphenyltetrazolium (MTT) assay. The antibacterial activity was tested using the minimum inhibitory concentration (MIC) assay. Twelve known compounds were isolated and identified by nuclear magnetic resonance spectroscopy (NMR). Additionally, forty volatile compounds were identified by means of headspace-solid phase microextraction with gas chromatography and mass spectrometry time of flight analysis (HS-SPME/GC-MS-TOF). The main volatile compounds detected include nonanal (18.82\%), $\alpha$-pinene $(12.45 \%)$, neryl alcohol $(10.13 \%)$, and $\alpha$-pinene $(8.04 \%)$. EEP showed an anti-proliferative effect on glioma cells better than temozolomide, also decreased proliferation and viability in cervical cancer cells, but its effectiveness was lower compared to cisplatin.
\end{abstract}

Keywords: propolis; antioxidant activity; cytotoxic; antibacterial; México; HS-SPME/GC-MS-TOF; NMR; volatile compounds; flavonoids; phenolic acids

\section{Introduction}

Propolis also known as "bee glue" is a nontoxic hive product accumulated by bees from diverse plants containing compounds such as flavonoid aglycones, phenolic acids and their esters, phenolic aldehydes, alcohols, ketones, sesquiterpenes, coumarins, steroids, amino acids, and inorganic compounds. It functions in sealing holes, cracks, reconstruction, and smothering the inner surfaces of the beehive. Propolis and its extracts have application in treating diseases due its anti-inflammatory, antioxidant, antibacterial, antimycotic, antifungal, antiulcer, anticancer, and immunomodulatory properties [1,2]. Egyptians, Greeks, Romans, Chinese, Arabs, and Incas have traditionally used it as an 
antiseptic to treat wounds and as an anti-pyretic agent [1-3]. The term propolis was described in the 16th Century in France and was considered as an official drug by London Pharmacopoeia [4].

Propolis contains mainly hydrophobic terpenes and phenolics compounds and can be classified in five types. The chemogeographic patterns of propolis types reflects the geographical distribution of plants species [2]. According to this distribution, the propolis produced in North America belongs to the poplar propolis and contains mainly flavonoids without B-ring substituents, such as pinocembrin, pinobanksin, galangin, and chrysin $[2,5]$.

In recent years, it has gained wide acceptance as traditional medicine in various parts of the world where it is claimed to improve human health and to prevent diseases such as diabetes and cancer $[6,7]$. Nowadays, in several countries, it is possible to find propolis as liquid extracts in bottles, vaporizers, syrups capsules, tablets, candies, creams, among others [8,9].

Data about the chemical composition and biological activity of propolis from México is limited [10-12]. Propolis in Atliplano region is prepared in several forms, including syrups, tinctures, and creams as an alternative to improve health and prevent diseases. In view of the importance of propolis in Mexican traditional medicine the chemical composition and biological activities (antioxidant, antibacterial, and cytotoxic) of the ethanolic extract of Altiplano propolis (EEP) were investigated.

The aims of this study were: (a) To isolate the major compounds of brown Mexican propolis, and (b) to evaluate the antibacterial, antioxidant, and cytotoxic activities of the EEP.

\section{Materials and Methods}

\subsection{Chemicals and Reagents}

All the chemicals to investigate the antioxidant, antibacterial, and cytotoxic activities were supplied by Sigma-Aldrich (St. Louis, MO, USA). All the solvents and chromatographic supports were purchased from Merck (Darmstadt, Germany). Deuterated solvents and TMS were provided by Cambridge Isotope Laboratories (Tewksbury, MA, USA).

\subsection{Instrumentation}

Nuclear magnetic resonance (NMR) spectra were taken on a Bruker AVANCE III $400(400 \mathrm{MHz})$ spectrometer, using tetramethylsilane (TMS) as an internal standard.

\subsection{Propolis Samples}

Beekeepers kindly provided four raw propolis samples from Silao and Irapuato, Guanajuato, México (Table 1). The samples were harvested using traps in 2018 and 2019 and were frozen and stored at $-20{ }^{\circ} \mathrm{C}$ until analysis.

Table 1. Location of recollection, harvesting method, and weight recollected.

\begin{tabular}{ccccc}
\hline Code & Location of Recollection & Year of Recollection & Harvesting Method & Weight (g) \\
\hline GUA-1 & Silao & 2018 & plastic nest & 6.0 \\
GUA-2 & Irapuato & 2018 & plastic nest & 8.50 \\
GUA-3 & Irapuato & 2019 & plastic nest & 6.95 \\
GUA-4 & Silao & 2019 & plastic nest & 32.0 \\
\hline
\end{tabular}

\subsection{Antioxidant Activity}

The EEP antioxidant activity was assessed using two different assays in vitro: DPPH and ABTS. Both methods were modified and translated into 96-well plates. Each test was done in three replicates.

Radical scavenging activity (RSA) for DPPH was evaluated according to the method described in [11]. Briefly, an ethanolic solution of $0.208 \mathrm{mM}$ was added to $0.1 \mathrm{~mL}$ of different concentrations of extracts and pure compounds. The 96-well plate was maintained in a dark at room temperature for $20 \mathrm{~min}$ and the absorbance was recorded at $540 \mathrm{~nm}$. The RSA was calculated as: RSA $=100 \times\left(\mathrm{A}_{\text {control }}-\mathrm{A}_{\text {sample }}\right) / \mathrm{A}_{\text {control }}$, 
where $\mathrm{A}_{\text {control }}$ and $\mathrm{A}_{\text {sample }}$ are the absorbance. The $\mathrm{IC}_{50}$ values were calculated from the relationship curve of RSA versus concentrations of the respective sample curve.

The ABTS test was performed according to the methodology previously reported in $[13,14]$ and slightly modified. The RSA of the ABTS radical was calculated using the following equation: $\%$ inhibition $=100\left(\mathrm{~A}_{\text {control }}-\mathrm{A}_{\text {sample }}\right) / \mathrm{A}_{\text {control }}$. The $\mathrm{IC}_{50}$ was calculated from the scavenging activities $(\%)$ versus concentrations of the respective sample curve.

\subsection{Total Phenol and Total Flavonoid Content}

In this paper, we used spectrometric procedures for the quantification of the total phenolic and flavonoids content in propolis. The total phenol content in extracts was adapted from the method described by Singleton and Rossi [15]. The total flavonoid content was determined using the aluminum chloride reagent and the method described by Marquele et al. [16]. The total phenol content was expressed as mg equivalents of gallic acid/g of dry extract of propolis (EEP). The total flavonoid content was expressed as mg equivalents of quercetin/g of dry extract of propolis (EEP).

\subsection{Extraction and Isolation of Compounds 1-12 from EEP GUA-4}

The air-dried and powdered propolis samples GUA-4 were extracted with ethanol for up to one week and the resultant extract was concentrated in vacuo. A portion of ethanol-soluble extract (10.3 g) was subjected to a silica gel vacuum column chromatography (VLC) and eluted with a gradient mixture of dichloromethane-acetone (1:0 $\rightarrow$ 0:1) to give eight pooled fractions (F2-F8). Fractions F2, F4, and F7 showed the best antioxidant activity. Fraction F2 was chromatographed over a Sephadex LH-20 column and eluted with methanol to yield $\mathbf{1}(40 \mathrm{mg})$. Fraction F4, eluted with dichloromethane-acetone (9:1), was chromatographed over a Sephadex LH-20 column, using methanol as eluent, to give six fractions. Fraction F4-3 (100 mg) was separated by TLC with dichloromethane-acetone (99:1), followed by TLC with dichloromethane-acetone (98:2), to give $2(20 \mathrm{mg})$ and $3(65 \mathrm{mg})$. Fraction F5 was rechromatographed on a Sephadex LH-20 column using methanol as solvent to give six subfractions (F5-1: 10 mg; F5-2: 12.3 mg; F5-3: 17.5 mg; F5-4: 15.7 mg; F5-5: 25.3 mg; F5-6: 18.1 mg). Subfraction F5-1 yielded crystals of 4 . F5-5 (25.3 mg) yielded crystals of 5 (9.0 mg). Mother liquor was subjected to a preparative thin-layer chromatography (PTLC) with acetone-toluene (5:95) to give 6 . Subfraction F5-6 $(18.1 \mathrm{mg})$ yielded crystals of $7(11.0 \mathrm{mg})$. Fraction F7 was chromatographed on silica gel using a hexane-EtOAc gradient system to give five fractions (F7-1: $13.9 \mathrm{mg}$; F7-2: $517.7 \mathrm{mg}$; F7-3: $28.4 \mathrm{mg}$; F7-4: $16.7 \mathrm{mg}$; F7-5: $32.8 \mathrm{mg}$; F7-6: $56.8 \mathrm{mg}$; F7-7: $45.1 \mathrm{mg}$ ). Subfraction F7-1 was identified as 8. Subfraction F7-2 was chromatographed by RP-MPLC, using $\mathrm{H}_{2} \mathrm{O}-\mathrm{CH}_{3} \mathrm{CN}(1: 0 \rightarrow 0: 1)$ to afford five subfractions (F7-2.1: $125.3 \mathrm{mg}$; F7-2.2: $275.1 \mathrm{mg}$; F7-2.3: $67.8 \mathrm{mg}$; F7-2.4: $37.0 \mathrm{mg}$; F7-2.5: $12.3 \mathrm{mg}$ ). Subfraction F7-2.3 was identified as 9. Subfractions F7-2.4, F7-2.5, and F7-2.6 were dissolved in $\mathrm{CH}_{2} \mathrm{Cl}_{2}-\mathrm{MeOH}$ and left overnight to give crystals of 10,11 , and 12 , respectively.

\subsection{Head Space Solid Phase Microextraction (HS-SPME), GC-MS Analysis, and Identification of Volatile Components}

The HS-SPME was performed using a Stableflex ${ }^{\circledR}$ fiber 50/30 $\mu \mathrm{m}$ DVB/CAR/PDMS $(1 \mathrm{~cm})$ as described in our previous work [17].

The analysis of volatile compounds was carried out on a GC Agilent $6890 \mathrm{~N}$ (Agilent Technology, Santa Clara, CA, USA) series gas chromatograph coupled to a LECO time of flight mass spectrometer (LECO Corporation, St. Joseph, MI, USA). The volatile compounds were separated on a $\%$ diphenyl-95\% dimethyl polysiloxane ( $30 \mathrm{~m} \times 0.18 \mathrm{~mm}$ i.d.; $0.18 \mu \mathrm{m}$ film thickness) capillary column (Bellefonte, PA, USA). The carrier gas was helium with a flow rate of $1 \mathrm{~mL} / \mathrm{min}$ and split ratio of 1:50. The column initial temperature was $40{ }^{\circ} \mathrm{C}$. It was then raised to $300{ }^{\circ} \mathrm{C}$ with a rate of $20{ }^{\circ} \mathrm{C} / \mathrm{min}$ and was held for $5 \mathrm{~min}$. The ionization electron energy was $70 \mathrm{eV}$ and the mass range scanned was $40-400 \mathrm{~m} / \mathrm{z}$. The injector and MS transfer were set at 300 and $250{ }^{\circ} \mathrm{C}$, respectively. The volatile constituents of propolis were identified by co-injection of the sample with standard samples when available; based 
on their Kovats Index, calculated in relation to the retention times of a series of alkanes (C-8-C-20), in comparison with those of the chemical compounds gathered by Adams [18] and by comparing their MS fragmentation patterns with those of pure compounds in the spectral database of the National Institute of Standards and Technology (NIST) [19].

\subsection{Cell Culture}

Rat C6 glioma cell and human cervical cancer cell lines (HeLa, SiHa, and CaSki) were obtained from American Type Culture Collection (Manassas, VA, USA). Cells were routinely maintained in Dulbecco's modified Eagle's medium (DMEM) supplemented with fetal bovine serum (Gibco BRL) with $5 \%$ for $\mathrm{C} 6$ cells and $10 \%$ for cervical cancer cells, and incubated at $37{ }^{\circ} \mathrm{C}$ in an atmosphere comprising $5 \% \mathrm{CO}_{2}$ and $95 \%$ air at high humidity. Cells were harvested with $0.025 \%$ trypsin and $0.01 \%$ EDTA (Gibco BRL).

The effect of EEP, cisplatin, and temozolomide on the proliferation of cells were evaluated using the MTT assay (3-(3,5-dimethylthiazol-2-yl)2,5-diphenyltetrazolium), which is based on the reduction of a tetrazolium salt in metabolically active cells. The procedure was as follows. Viable cells were seed into 96-well plates in $100 \mu \mathrm{L}$ per well of DMEM culture medium at a density of $3 \times 10^{3}$ for C6 cells, $2 \times 10^{4}$ for CaSki cells, and $1 \times 10^{4}$ cells for HeLa and SiHa cells. After treatment, the medium was removed and the MTT solution was added to each well, followed by 1 to $2 \mathrm{~h}$ in a humidified atmosphere containing $5 \% \mathrm{CO}_{2}$ at $37^{\circ} \mathrm{C}$. The absorbance of the samples was measured spectrophotometrically at $\lambda 570 \mathrm{~nm}$ using a microtiter plate ELISA reader. Results are expressed as the percentage of MMT reduction.

C6 cells were exposed for $72 \mathrm{~h}$ with 2 to $200 \mu \mathrm{g} / \mathrm{mL}$ of EEP, since it is the time used to make the exposure with temozolomide (first line treatment used for glioblastoma), whereas HeLa, $\mathrm{SiHa}$, and CaSki cells were exposed for $24 \mathrm{~h}$ with 15 to $500 \mu \mathrm{g} / \mathrm{mL}$ of EEP; after that time, cell viability was quantified using the MTT assay. Temozolomide $(250 \mu \mathrm{M})$ and cisplatin $(5-320 \mu \mathrm{M})$ were used as a control. The concentration of drugs to reach $50 \%$ growth inhibition $\left(\mathrm{IC}_{50}\right)$ was obtained from the survival curves. The experiments were conducted in triplicate in independent experiments. Values are expressed as the mean \pm SEM of at least three independent experiments. SigmaPlot 12.3 software (Systat Software, Santa Clara, CA, USA) was used.

\subsection{Antibacterial Activity}

The in vitro antibacterial activity of EEP and compounds 1-4, 10-13, and 15-17 were determined using a broth microdilution test as recommended by Clinical and Laboratory Standards Institute (New York, NY, USA) M7-A11 for bacteria [20]. The minimum inhibitory concentration (MIC) was defined as the lowest concentration of the test agent that had restricted growth to a level $<0.05$ at 660 $\mathrm{nm}$ after incubation at $37^{\circ} \mathrm{C}$ for $16-24 \mathrm{~h}$.

\section{Results and Discussion}

\subsection{Total Phenol and Flavonoid Content}

The total polyphenol contents for the selected propolis samples were found to be $178.9 \pm 5.7$, $198.4 \pm 4.1,167.6 \pm 7.8$, and $246.3 \pm 3.2 \mathrm{mg} \mathrm{GAE} / \mathrm{g}$ of dry extract for GUA-1, GUA-2, GUA-3, and GUA-4, respectively. It should be noted that the Folin-Ciolcateau reagent was reported in the literature as not specific to only phenols and could react with other reducing compounds that could be oxidized by the Folin reagent [21]. The total flavonoid contents were $64.32 \pm 5.75,58.34 \pm 2.8,77.45 \pm 6.9$, and $87.5 \pm 1.9 \mathrm{mg}$ QE/g of dry extract for GUA-1, GUA-2, GUA-3, and GUA-4, respectively. Flavonoids can form complexes with aluminum chloride to yield a yellow solution. Valencia et al. [22] has been reported values of $629.6 \pm 9.9 \mathrm{mg} \mathrm{GAE} / \mathrm{g}$ of dry extract for TPC and $185.9 \pm 3.2 \mathrm{mg}$ QE/g of dry extract and TF in a propolis from Sonora, México. The most important flavonoids isolated in this propolis sample were pinocembrin, pinobanksin 3-acetate, and chrysin. The results also confirm the influence of the geographic region and the season of collection for the quality and properties of the propolis [2]. 


\subsection{Antioxidant Activity Assays}

The EEP was evaluated for its ability to quench the DPPH', which is one of the few stable organic nitrogen radicals and bears a purple colour. This assay is based on the measurement of the loss of $\mathrm{DPPH}^{\bullet}$ after reaction with samples. It is considered as the prior mechanism involved in the electron transfer. The $\mathrm{IC}_{50}$ value is a parameter widely used to measure the antioxidant activity of test samples. It is calculated as the concentration of antioxidants needed to decrease the initial DPPH concentration by $50 \%$ [23]. Thus, the lower $\mathrm{IC}_{50}$ value the higher antioxidant activity. The EEP GUA-4 showed an antioxidant activity $\left(\mathrm{IC}_{50}=67.9 \mu \mathrm{g} / \mathrm{mL}\right)$ comparable to the reference ascorbic acid $\left(\mathrm{IC}_{50}=43.2 \mu \mathrm{g} / \mathrm{mL}\right)$ and tenfold lower than Trolox $\left(\mathrm{IC}_{50}=6.3 \mu \mathrm{g} / \mathrm{mL}\right)$ and seven-fold lower than quercetin $\left(\mathrm{IC}_{50}=9.9 \mu \mathrm{g} / \mathrm{mL}\right)$. While caffeic acid (12) showed the highest activity $\left(\mathrm{IC}_{50}=5.9 \mu \mathrm{g} / \mathrm{mL}\right)$ along with ferulic acid (10) $\left(\mathrm{IC}_{50}=9.9 \mu \mathrm{g} / \mathrm{mL}\right)$ and syringic acid $(11)\left(\mathrm{IC}_{50}=9.8 \mu \mathrm{g} / \mathrm{mL}\right)$. The lowest antioxidant activity corresponds to 5-methylchrysin ether $(9)\left(\mathrm{IC}_{50}=112.9 \mu \mathrm{g} / \mathrm{mL}\right)$ and 5-methyl-pinobanksin ether (5) $\left(\mathrm{IC}_{50}=98.4 \mu \mathrm{g} / \mathrm{mL}\right)$.

There are reports of the DPPH scavenging capacity, in terms of $\mathrm{IC}_{50}$, for pinocembrin (1), chrysin (2), galangin (3), isorhamnetin (7), ferulic acid (10), syringic acid, (11) and caffeic acid (12) [23-26]. For alpinetin (4) only the percentage of scavenging activity of DPPH is reported [27]. Nevertheless, the information available for dillenetin (6), 5-methyl-pinobanksin ether (5), 5-methylchrysin ether (9), and 5-methylgalangin ether (8) is scarce. Thus, the present work stands for the first report of the $\mathrm{IC}_{50}$ as a measurement of their antioxidant activity (Table 2).

In the ABTS assay, the antioxidant activity is measured as the ability of test compounds to decrease the color reacting directly with the radical ABTS• ${ }^{+}$[28]. Ferulic acid (10), syringic acid (11), caffeic acid (12), and chrysin (2) showed the lowest $\mathrm{IC}_{50}$ (Table 2). The EEP, 5-methylchrysin ether (9), and 5-methyl-pinobanksin ether (5) showed weak antioxidant activity (Table 2).

The analysis of their chemical structures can explain the weak antioxidant activity of the methylated flavonoids. According to Procházková et al. [29] the catechol structure in the B-ring, 2,3-double bond in conjugation with a 4-oxo function in the C-ring and the hydroxyl groups in meta position in ring-A. On the other hand, the activity of phenolic acids lies on the presence of two $o$-hydroxyl groups in the aromatic ring.

Table 2. Scavenging ability of ethanol extract of propolis (EEP) GUA-4 and compounds 1-12.

\begin{tabular}{ccc}
\hline & \multicolumn{2}{c}{ IC $_{\mathbf{5 0}}(\boldsymbol{\mu g} / \mathbf{m L})$} \\
\cline { 2 - 3 } Compounds & DPPH & ABTS \\
\hline EEP GUA-4 & $67.9 \pm 0.1$ & $98.7 \pm 0.5$ \\
pinocembrin (1) & $23.5 \pm 1.8$ & $44.8 \pm 2.1$ \\
chrysin (2) & $10.7 \pm 0.2$ & $16.3 \pm 0.8$ \\
galangin (3) & $15.3 \pm 0.5$ & $26.8 \pm 0.1$ \\
alpinetin (4) & $47.3 \pm 1.9$ & $69.5 \pm 0.7$ \\
dillenetin (6) & $98.4 \pm 2.3$ & $126.9 \pm 4.5$ \\
isorhamnetin (7) & $35.7 \pm 3.5$ & $48.9 \pm 2.9$ \\
5-methylgalangin ether (8) & $21.4 \pm 3.1$ & $36.7 \pm 4.6$ \\
5-methylchrysin ether (9) & $63.2 \pm 2.6$ & $94.2 \pm 6.2$ \\
ferulic acid (10) & $112.9 \pm 1.9$ & $158.4 \pm 4.9$ \\
syringic acid (11) & $9.9 \pm 0.7$ & $16.7 \pm 0.2$ \\
caffeic acid (12) & $9.8 \pm 0.4$ & $13.0 \pm 0.9$ \\
Quercetin & $5.9 \pm 0.4$ & $9.7 \pm 0.5$ \\
Trolox & $9.9 \pm 2.5$ & $16.1 \pm 2.1$ \\
ascorbic acid & $6.3 \pm 1.4$ & $3.8 \pm 1.2$ \\
\hline
\end{tabular}




\subsection{Cytotoxicity of EEP on Cancer Cells}

Cytotoxicity was expressed as the percentage grow inhibition of C6, HeLa, SiHa, and CaSki cells treated with EEP. In all the cases, EEP shows a cytotoxicity concentration-depended manner. In Table 3, we show the $\mathrm{IC}_{50}$ value of EEP over four cancer cell lines. Those results show that EEP restricts glioblastoma cells (C6 cell cancer line) proliferation in vitro as efficiently as temozolomide (reference drug), whereas, for cervical cancer cell lines, it requires a higher concentration of the EEP compared to cisplatin.

There are a few studies of beneficial properties of Mexican propolis. Li et al. [11] reported that three of the 39 compounds isolated from the methanolic extract of Mexican propolis exhibited a potent cytotoxic effect in a colon, melanoma, lung, cervix, and fibrosarcoma cancer cell lines. Li et al. reported the isolation of flavonoids from methanolic extract of Mexican propolis, and one of them revealed significant cytotoxic effect against pancreatic human cancer cell line with $\mathrm{IC}_{50}$ values of $4 \mu \mathrm{M}$ [10]. Other studies described the potent cytotoxic activity of galangin (3); ferulic acid (10); syringic acid (11); and caffeic acid (12) against different cancer cell lines [22]. Interestingly, a few researchers reported that these compounds could be useful for therapeutic treatments. For example, Benguedouar et al. [30] reported that ethanolic extract of Algerian propolis (EEP) and galangin (3) decreased the number of B16F1 melanoma cells in vitro compared to control. Celinska-Janowicz et al. [31] state that the ethanolic extract of propolis isolated abundant polyphenolic compounds such as ferulic acid (10) and caffeic acid (12) revealed pro-apoptotic activity on human tongue squamous carcinoma cells (CAL-27). From this information, we emphasized that EEP and compounds possesses anti-cancer effects against cancer cell lines.

Table 3. Cytotoxic effect of EEP on several cancer cell lines.

\begin{tabular}{|c|c|c|c|}
\hline Cell Line & $\mathrm{IC}_{50}$ & Reference Drug & Reference Concentration \\
\hline C6 & $92.2 \mu \mathrm{g} / \mathrm{mL}$ & Temozolamide & $\begin{array}{c}\mathrm{IC}_{30} 250 \mu \mathrm{M} \\
(50 \mu \mathrm{g} / \mathrm{mL})\end{array}$ \\
\hline $\mathrm{HeLa}$ & $\begin{array}{l}>100 \mu \mathrm{g} / \mathrm{mL} \\
(357 \mu \mathrm{g} / \mathrm{mL})\end{array}$ & \multirow{3}{*}{ Cisplatin } & $\begin{array}{l}\mathrm{IC}_{50} 46 \mu \mathrm{M} \\
(14 \mu \mathrm{g} / \mathrm{mL})\end{array}$ \\
\hline $\mathrm{SiHa}$ & $\begin{array}{l}>100 \mu \mathrm{g} / \mathrm{mL} \\
(500 \mu \mathrm{g} / \mathrm{mL})\end{array}$ & & $\begin{array}{c}\mathrm{IC}_{50} 121 \mu \mathrm{M} \\
(36 \mu \mathrm{g} / \mathrm{mL})\end{array}$ \\
\hline CaSki & $\begin{array}{l}>100 \mu \mathrm{g} / \mathrm{mL} \\
(538 \mu \mathrm{g} / \mathrm{mL})\end{array}$ & & $\begin{array}{c}\mathrm{IC}_{50} 163 \mu \mathrm{M} \\
(50 \mu \mathrm{g} / \mathrm{mL})\end{array}$ \\
\hline
\end{tabular}

\subsection{Antibacterial Activity}

As shown in Table 4, antimicrobial screening against four oral pathogens revealed that compounds $\mathbf{1}, \mathbf{3}, \mathbf{4}, \mathbf{1 2}$, and 16 were inhibitory to the growth of Streptococcus mutans, Streptococcus oralis, Streptococcus sanguinis, and Phorphyromonas gingivalis. Among these, compounds 1, 3, 4, and 12, were either equally or more potent than their respective crude extract of origin (Table 4). Earlier in vitro studies have shown that the Sonoran ethanolic extract of propolis exhibited antibacterial activity against $E$. coli (ATCC 25922) and S. aureus (ATCC 6538P). The propolis constituents CAPE, pinocembrin, pinobanksin 3-O-acetate, and naringenin exhibited significant inhibitory activity on the growth of $S$. aureus. CAPE exhibited the maximum inhibitory effect on the bacterial growth (CAPE (MIC $0.1 \mathrm{mmol} / \mathrm{L}$ ), pinocembrin (MIC $0.4 \mathrm{mmol} / \mathrm{L}$ ), pinobanksin 3-O-acetate (MIC $0.8 \mathrm{mmol} / \mathrm{mL})$, and naringenin $(0.8 \mathrm{mmol} / \mathrm{L})$ ). None of the propolis constituents influenced the growth of E. coli at any of the tested concentrations [32]. 
Table 4. Antimicrobial activity of ethanolic extract and compounds $\mathbf{1 - 4}, \mathbf{1 0 - 1 3}, \mathbf{1 5}-\mathbf{1 7}$, and chlorhexidine digluconate $(\mathrm{CHX})^{\text {a }}$.

\begin{tabular}{|c|c|c|c|c|}
\hline \multirow{2}{*}{ Compounds } & \multicolumn{4}{|c|}{$\operatorname{MIC}^{b}(\mu \mathrm{g} / \mathrm{mL})$} \\
\hline & S. mutans & S. oralis & S. sanguinis & P. gingivalis \\
\hline EEP & 250 & 125 & 125 & 500 \\
\hline EOP & 500 & 500 & 500 & 1000 \\
\hline pinocembrin (1) & 256 & 128 & 128 & 512 \\
\hline chrysin (2) & 512 & 512 & 512 & 1024 \\
\hline galangin (3) & 256 & 256 & 256 & 1024 \\
\hline alpinetin (4) & 128 & 256 & 128 & 516 \\
\hline ferulic acid (10) & 500 & 250 & 250 & 500 \\
\hline syringic acid (11) & 250 & 250 & 250 & 500 \\
\hline caffeic acid (12) & 128 & 128 & 128 & 256 \\
\hline nonanal (13) & 256 & 256 & 128 & 512 \\
\hline neryl alcohol (15) & 1024 & 512 & 512 & 1024 \\
\hline$\alpha$-pinene (16) & 250 & 250 & 250 & 500 \\
\hline$\alpha$-pinene (17) & 500 & 500 & 500 & 500 \\
\hline a $\mathrm{CHX}$ & 0.02 & 0.02 & 0.02 & 0.12 \\
\hline
\end{tabular}

\subsection{Chemical Composition of EEP GUA-4}

The EtOH-soluble extract of sample GUA-4 was fractionated by chromatography on a VLC column and by Sephadex LH-20, giving 12 known compounds (1-12). The compounds were identified as pinocembrin $(\mathbf{1}, 405.4 \mathrm{mg})$ [33], chrysin $(\mathbf{2}, 126.3 \mathrm{mg})$ [34], galangin $(\mathbf{3}, 56.7 \mathrm{mg})$ [33], alpinetin (4, $15.6 \mathrm{mg})$ [35], 5-methyl-pinobanksin ether $(5,16.8 \mathrm{mg})$ [36], dillenetin $(6,12.3 \mathrm{mg})$ [37], isorhamnetin (7, $24.6 \mathrm{mg})$ [38], 5-methylgalangin ether (8,9.8 mg) [39], 5-methylchrysin ether (9, $16.3 \mathrm{mg})$ [40], ferulic acid (10, 24.9 mg) [33], syringic acid (11, $6.7 \mathrm{mg})$, and caffeic acid (12, $8.9 \mathrm{mg})$ [33] (Figure S1) by means of 1D (Table S1) and 2D NMR spectral analysis. The presence of pinocembrin (1), chrysin (2), galangin (3), ferulic acid (10), syringic acid (11), and caffeic acid (12) suggest that its main botanical source are a species of Populus typical of the country, such as Populus mexicana Wesmael, Populus guzmanantlensis Vazques and Cuevas and Populus simaroa Rzedowski. Although flavonoids without B-ring substituents appear common in temperate propolis from both the northern and southern hemispheres, in this study we report for the first time the presence of dillenetin (6) and isorhamnetin (7) with B-ring substitution as constituents of Mexican poplar propolis. To the best of our knowledge, this is the first report of dillenetin (6) as a propolis constituent. 5-methylpinobanksin (5), alpinetin (4), isorhamnetin (7), 5-methylgalangin ether (8), and 5-methylchrysin ether (9) were previously identified by diode array detection and ESI mass spectrometry (LC-DAD-ESI-MS) as constituents of Italian, Portuguese, and Czech propolis [41,42].

\subsection{Volatile Compounds}

Forty volatile constituents were identified as shown in Table 5. The typical analytical ion current (AIC) chromatogram is shown in Figure S2. The chemical composition of volatiles was found in agreement with previous reports [43]. The main volatile compounds identified were nonanal $(18.829 \%$, 13), $\beta$-pinene $(12.179 \%$, 14), 1-octen-3-ol $(12.129 \%$, 15), neryl alcohol $(10.135 \%, 16), \alpha$-pinene $(8.046 \%$, 17), 6-methyl-3,5-heptadiene-2-one $(6.803 \%, 18), p$-cymen-9-ol $(3.108 \%, 19)$, and sylvestrene $(3.022 \%$, 20) (Figure S3). It is important to note that the content of the compounds differed from a previous study carried out on the volatile compounds in propolis samples from Yucatan (México). In that sample, hexadecanoic acid (10.9\%) and trans-verbenol (7.0\%) were the predominant compounds [44]. 
Table 5. Volatile components from Mexican propolis GUA-4.

\begin{tabular}{|c|c|c|c|c|}
\hline & Name & Retention Index & Area \% & Method of Identification \\
\hline 1 & $\alpha$-pinene & 939 & 8.046 & $a, b, c$ \\
\hline 2 & $\beta$-pinene & 979 & 12.179 & $a, b, c$ \\
\hline 3 & 1-octen-3-ol & 982 & 12.129 & $a, b$ \\
\hline 4 & ethyl hexanoate & 1003 & 0.042 & $a, b, c$ \\
\hline 5 & Octanal & 1006 & 1.273 & $a, b$ \\
\hline 6 & Sylvestrene & 1030 & 3.022 & $a, b$ \\
\hline 7 & acetophenone & 1076 & 0.486 & $a, b$ \\
\hline 8 & 1-octanol & 1078 & 0.107 & $a, b$ \\
\hline 9 & Thujone & 1102 & 0.276 & $a, b$ \\
\hline 10 & $p$-cymenene & 1082 & 0.291 & $a, b$ \\
\hline 11 & Nonanal & 1100 & 18.829 & $a, b, c$ \\
\hline 12 & 6-methyl-3,5-heptadiene-2-one & 1105 & 6.803 & $a, b$ \\
\hline 13 & Eucalyptol & 1039 & 0.472 & $a, b, c$ \\
\hline 14 & Camphor & 1146 & 0.583 & $a, b, c$ \\
\hline 15 & trans-pinocamphone & 1162 & 2.386 & $a, b$ \\
\hline 16 & trans-terpineol & 1163 & 0.102 & $a, b$ \\
\hline 17 & $p$-menth-1,5-dien-8-ol & 1167 & 1.097 & $a, b$ \\
\hline 18 & $(2 E)$-nonenal & 1168 & 1.097 & $a, b$ \\
\hline 19 & m-cymen-8-ol & 1180 & 1.024 & $a, b, c$ \\
\hline 20 & Unknown 1 & 1185 & 0.064 & - \\
\hline 21 & $\alpha$-terpineol & 1189 & 1.571 & $a, b$ \\
\hline 22 & Myrtenol & 1193 & 1.571 & $a, b$ \\
\hline 23 & D-fenchone & 1187 & 1.828 & $a, b$ \\
\hline 24 & $p$-cymen-9-ol & 1207 & 3.108 & $a, b, c$ \\
\hline 25 & neryl alcohol & 1217 & 10.135 & $a, b$ \\
\hline 26 & trans-carveol & 1219 & 2.953 & $a, b$ \\
\hline 27 & Citronellol & 1228 & 1.916 & $a, b$ \\
\hline 28 & Ocimenone & 1230 & 0.727 & $a, b$ \\
\hline 29 & cis-chrysanthenyl acetate & 1253 & 0.243 & $a, b$ \\
\hline 30 & Geraniol & 1278 & 0.314 & $a, b$ \\
\hline 31 & neodehydro carveol acetate & 1307 & 1.843 & $a, b$ \\
\hline 32 & ethyl nonanoate & 1319 & 1.283 & $a, b$ \\
\hline 33 & trans-carvyl acetate & 1337 & 0.357 & $a, b$ \\
\hline 34 & $\alpha$-longipinene & 1352 & 0.181 & $a, b$ \\
\hline 35 & $\beta$-cububene & 1388 & 0.248 & $a, b$ \\
\hline 36 & $\beta$-bourbonene & 1398 & 0.217 & $a, b$ \\
\hline 37 & n-decyl acetate & 1408 & 0.109 & $a, b$ \\
\hline 38 & trans-geranylacetone & 1455 & 0.429 & $a, b$ \\
\hline 39 & $\gamma$-gelinene & 1485 & 0.103 & $a, b$ \\
\hline 40 & $\beta$-bisabolene & 1509 & 0.290 & $a, b$ \\
\hline
\end{tabular}

a: Retention time; b: Retention index; c: Mass spectrum.

\section{Conclusions}

In the present study, we have isolated twelve (1-12) components and identified 40 volatile compounds in Mexican propolis. The current study revealed the presence of antioxidant, antimicrobial, and cytotoxic phytochemicals [galangin (3); ferulic acid (10); syringic acid (11); and caffeic acid (12)] in EEP. It is concluded that EEP can be a potential addition in pharmaceutical products for the improvement of human health by contributing in the antioxidant defense system fighting against the production of free radicals. México, being a megadiverse country, has numerous numbers of propolis differing in chemical composition. However, unfortunately it is still unexplored.

Supplementary Materials: The following are available online at http://www.mdpi.com/2076-3921/9/1/70/s1, Figure S1: Flavonoids isolated from EEP GUA-4; Figure S2: Analytical ion current chromatogram (AIC) of propolis 
GUA-4; Figure S3: Major volatile compounds of EEP GUA-4; Table S1: ${ }^{1} \mathrm{H}-\mathrm{RMN}$ data of the flavonoids isolated from Mexican propolis.

Author Contributions: J.G.-P. performed the phytochemical study; J.F.R.-C. conceived and designed the phytochemical experiments and wrote the paper; J.M.P.-R. conceived and designed the in vitro experiments; A.K.-P.reviewed of the manuscript and contributed with in vitro experiments; G.D.-R. contributed with the antimicrobial assays; J.P.-C. reviewed the manuscript and contributed with in vitro experiments; B.E.R.-C. reviewed of the manuscript and contributed with in vitro experiments. All authors have read and agreed to the published version of the manuscript.

Funding: This research was funded by CONACyT CB-252006 and College of Chemistry, National Autonomous University of Mexico under the PAIP 5000-9138 Fellowship Scheme.

Acknowledgments: We are in debt to Médico Veterinario Zootecnista. Ángel López-Ramírez for technical assistance in propolis recolection. Jessica Granados Pineda is a doctoral student from the Programa de Doctorado en Ciencias Químicas, Universidad Nacional Autónoma de México (UNAM), Facultad de Química, and recieved a CONACyT fellowship \# 273461. The authors wish to thank the technical assistance of Georgina Duarte-Lisci and Juan Rojas-Moreno.

Conflicts of Interest: The authors declare no conflict of interest.

\section{References}

1. Bankova, V.; Bertelli, D.; Borba, R.; Conti, B.J.; da Silva Cunha, I.B.; Danert, C.; Eberlin, M.N.; I Falcão, S.; Isla, M.I.; Moreno, M.I.N.; et al. Standard methods for Apis mellifera propolis research. J. Apic. Res. 2016, 58, 1-49. [CrossRef]

2. Salatino, A.; Fernandes-Silva, C.C.; Righi, A.A.; Salatino, M.L. Propolis research and the chemistry of plant products. Nat. Prod. Res. 2011, 28, 925-936. [CrossRef] [PubMed]

3. Kuropatnicki, A.K.; Szliszka, E.; Krol, W. Historical aspects of propolis research in modern times. Evid. Based Cmnplement. Altern. Med. eCAM 2013, 2013, 964149. [CrossRef] [PubMed]

4. Toreti, V.C.; Sato, H.H.; Pastore, G.M.; Park, Y.K. Recent progress of propolis for its biological and chemical compositions and its botanical origin. Evid. Based Cmnplement. Altern. Med. eCAM 2013, 2013, 697390. [CrossRef]

5. Christov, R.; Trusheva, B.; Popova, M.; Bankova, V.; Bertrand, M. Chemical composition of propolis from canada, its antiradical activity and plant origin. Nat. Prod. Res. 2006, 20,531-536. [CrossRef]

6. Karapetsas, A.; Voulgaridou, G.-P.; Konialis, M.; Tsochantaridis, I.; Kynigopoulos, S.; Lambropoulou, M.; Stavropoulou, M.-I.; Stathopoulou, K.; Aligiannis, N.; Bozidis, P.; et al. Propolis extracts inhibit UV-induced photodamage in human experimental in vitro skin models. Antioxidants 2019, 8, 125. [CrossRef]

7. Nna, V.U.; Abu Bakar, A.B.; Ahmad, A.; Eleazu, C.O.; Mohamed, M. Oxidative stress, NF-kb-mediated inflammation and apoptosis in the testes of streptozotocin-induced diabetic rats: Combined protective effects of malaysian propolis and metformin. Antioxidants 2019, 8, 465. [CrossRef]

8. Papotti, G.; Bertelli, D.; Bortolotti, L.; Plessi, M. Chemical and functional characterization of italian propolis obtained by different harvesting methods. J. Agric. Food. Chem. 2012, 60, 2852-2862. [CrossRef]

9. Navarro-Navarro, M.; Ruiz-Bustos, P.; Valencia, D.; Robles-Zepeda, R.; Ruiz-Bustos, E.; Virues, C.; Hernandez, J.; Dominguez, Z.; Velazquez, C. Antibacterial activity of sonoran propolis and some of its constituents against clinically significant vibrio species. Foodborne Pathog. Dis. 2013, 10, 150-158. [CrossRef]

10. Li, F.; Awale, S.; Tezuka, Y.; Esumi, H.; Kadota, S. Study on the constituents of mexican propolis and their cytotoxic activity against panc-1 human pancreatic cancer cells. J. Nat. Prod. 2010, 73, 623-627. [CrossRef]

11. Li, F.; Awale, S.; Tezuka, Y.; Kadota, S. Cytotoxicity of constituents from mexican propolis against a panel of six different cancer cell lines. Nat. Prod. Commun. 2010, 5, 1601-1606. [CrossRef] [PubMed]

12. Lotti, C.; Campo Fernandez, M.; Piccinelli, A.L.; Cuesta-Rubio, O.; Marquez Hernandez, I.; Rastrelli, L. Chemical constituents of red mexican propolis. J. Agric. Food Chem. 2010, 58, 2209-2213. [CrossRef] [PubMed]

13. Cheng, Z.; Moore, J.; Yu, L. High-throughput relative DPPH radical scavenging capacity assay. J. Agric. Food Chem. 2006, 54, 7429-7436. [CrossRef] [PubMed]

14. Zhao, H.; Fan, W.; Dong, J.; Lu, J.; Chen, J.; Shan, L.; Lin, Y.; Kong, W. Evaluation of antioxidant activities and total phenolic contents of typical malting barley varieties. Food Chem. 2007, 107, 296-304. [CrossRef] 
15. Singleton, V.L.; Rossi, J.A. Colorimetry of total phenolics with phosphomolybdic-phosphotungstic acid reagents. Am. J. Enol. Vit. 1965, 16, 144-158.

16. Marquele, F.D.; Di Mambro, V.M.; Georgetti, S.R.; Casagrande, R.; Valim, Y.M.L.; Fonseca, M.J.V. Assessment of the antioxidant activities of brazilian extracts of propolis alone and in topical pharmaceutical formulations. J. Pharm. Biomed. Anal. 2005, 39, 455-462. [CrossRef]

17. Torres-González, A.; López-Rivera, P.; Duarte-Lisci, G.; López-Ramírez, Á.; Correa-Benítez, A.; Rivero-Cruz, J.F. Analysis of volatile components from Melipona beecheii geopropolis from Southeast Mexico by headspace solid-phase microextraction. Nat. Prod. Res. 2016, 30, 237-240. [CrossRef]

18. Adams, R.P. Identification of Essential Oil Components by Gas Chromatography/Mass Spectrometry; Allured Publishing Corporation: Carol Stream, IL, USA, 2007.

19. Linstrom, P.J. NIST Chemistry Webbook, NIST Standard Reference Database Number 69; National Institute of Standards and Technology: Gaithersburg, MD, USA, 2005.

20. Clinical and Laboratory Standards Institute. Methods for Dilution Antimicrobial Susceptibility Tests for Bacteria that Grow Aerobically, Approved Standard, 10th ed.; M07-A11; Clinical and Laboratory Standards Institute: Wayne, PA, USA, 2018.

21. Escarpa, A.; González, M. Approach to the content of total extractable phenolic compounds from different food samples by comparison of chromatographic and spectrophotometric methods. Anal. Chim. Acta 2001, 427, 119-127. [CrossRef]

22. Valencia, D.; Alday, E.; Robles-Zepeda, R.; Garibay-Escobar, A.; Galvez-Ruiz, J.C.; Salas-Reyes, M.; Jimenez-Estrada, M.; Velazquez-Contreras, E.; Hernandez, J.; Velazquez, C. Seasonal effect on chemical composition and biological activities of sonoran propolis. Food Chem. 2012, 131, 645-651. [CrossRef]

23. Sánchez-Moreno, C.; Larrauri, J.A.; Saura-Calixto, F. A procedure to measure the antiradical efficiency of polyphenols. J. Sci. Food Chem. 1998, 76, 270-276. [CrossRef]

24. Lima, B.; Tapia, A.; Luna, L.; Fabani, M.P.; Schmeda-Hirschmann, G.; Podio, N.S.; Wunderlin, D.A.; Feresin, G.E. Main flavonoids, dpph activity, and metal content allow determination of the geographical origin of propolis from the province of San Juan (Argentina). J. Agric. Food Chem. 2009, 57, 2691-2698. [CrossRef] [PubMed]

25. Tominaga, H.; Kobayashi, Y.; Goto, T.; Kasemura, K.; Nomura, M. DPPH radical-scavenging effect of several phenylpropanoid compounds and their glycoside derivatives. Yakugaku Zasshi J. Pharm. Soc. Jpn. 2005, 125, 371-375. [CrossRef] [PubMed]

26. Pengfei, L.; Tiansheng, D.; Xianglin, H.; Jianguo, W. Antioxidant properties of isolated isorhamnetin from the sea buckthorn marc. Plant Foods Hum. Nutr. 2009, 64, 141-145. [CrossRef] [PubMed]

27. Lu, H.T.; Zou, Y.L.; Deng, R.; Shan, H. Extraction, purification and antiradical activities of alpinetin and cardamomin from alpinia katsumadai hayata. Asian J. Chem. 2013, 25, 9503-9507. [CrossRef]

28. Prior, R.L.; Wu, X.; Schaich, K. Standardized methods for the determination of antioxidant capacity and phenolics in foods and dietary supplements. J. Agric. Food Chem. 2005, 53, 4290-4302. [CrossRef]

29. Procházková, D.; Boušová, I.; Wilhelmová, N. Antioxidant and prooxidant properties of flavonoids. Fitoterapia 2011, 82, 513-523. [CrossRef]

30. Benguedouar, L.; Lahouel, M.; Gangloff, S.C.; Durlach, A.; Grange, F.; Bernard, P.; Antonicelli, F. Ethanolic extract of Algerian propolis and galangin decreased murine melanoma T. Anticancer Agents Med. Chem. 2016, 16, 1172-1183. [CrossRef]

31. Celińska-Janowicz, K.; Zaręba, I.; Lazarek, U.; Teul, J.; Tomczyk, M.; Pałka, J.; Miltyk, W. Constituents of Propolis: Chrysin, Caffeic Acid, p-Coumaric Acid, and Ferulic Acid Induce PRODH/POX-Dependent Apoptosis in Human Tongue Squamous Cell Carcinoma Cell (CAL-27). Front. Pharmacol. 2018, 9, 336. [CrossRef]

32. Velazquez, C.; Navarro, M.; Acosta, A.; Angulo, A.; Dominguez, Z.; Robles, R.; Robles-Zepeda, R.; Lugo, E.; Goycoolea, F.M.; Velazquez, E.F.; et al. Antibacterial and free-radical scavenging activities of Sonoran propolis. J. Appl. Microbiol. 2007, 103, 1747-1756. [CrossRef]

33. Bertelli, D.; Papotti, G.; Bortolotti, L.; Marcazzan, G.L.; Plessi, M. ${ }^{1}$ H-NMR simultaneous identification of health-relevant compounds in propolis extracts. Phytochem. Anal. 2012, 23, 260-266. [CrossRef]

34. Wawer, I.; Zielinska, A. 13c cp/mas nmr studies of flavonoids. Magn. Reson. Chem. 2001, 39, 374-380. [CrossRef] 
35. Dominguez, X.A.; Franco, R.; Zamudio, A.; Barradas, D.D.M.; Watson, W.H.; Zabel, V.; Merijanian, A. Mexican medicinal plants. Part 38. Flavonoids from Dalea scandens var. Paucifolia and Dalea thyrsiflora. Phytochemistry 1980, 19, 1262-1263. [CrossRef]

36. Rossi, M.H.; Yoshida, M.; Soares Maia, J.G. Neolignans, styrylpyrones and flavonoids from an aniba species. Phytochemistry 1997, 45, 1263-1269. [CrossRef]

37. Hosny, M.; Dhar, K.; Rosazza, J.P.N. Hydroxylations and methylations of quercetin, fisetin, and catechin by Streptomyces griseus. J. Nat. Prod. 2001, 64, 462-465. [CrossRef] [PubMed]

38. Cao, X.; Wei, Y.; Ito, Y. Preparative isolation of isorhamnetin from Stigma maydis using high-speed countercurrent chromatography. J. Liq. Chromatogr. Relat. Technol. 2009, 32, 273-280. [CrossRef] [PubMed]

39. Nagy, M.; Suchy, V.; Uhrin, D.; Ubik, K.; Budesinsky, M.; Grancai, D. Constituents of propolis of Czechoslovak origin. V. Chem. Pap. 1988, 42, 691-696.

40. Falcão, S.; Vilas-Boas, M.; Estevinho, L.; Barros, C.; Domingues, M.M.; Cardoso, S. Phenolic characterization of northeast portuguese propolis: Usual and unusual compounds. Anal. Bioanal. Chem. 2010, 396, 887-897. [CrossRef]

41. Gardana, C.; Scaglianti, M.; Pietta, P.; Simonetti, P. Analysis of the polyphenolic fraction of propolis from different sources by liquid chromatography-tandem mass spectrometry. J. Pharm. Biomed. Anal. 2007, 45, 390-399. [CrossRef]

42. Falcao, S.I.; Vale, N.; Gomes, P.; Domingues, M.R.M.; Freire, C.; Cardoso, S.M.; Vilas-Boas, M. Phenolic profiling of portuguese propolis by LC-MS spectrometry: Uncommon propolis rich in flavonoid glycosides. Phytochem. Anal. 2013, 24, 309-318. [CrossRef]

43. Pellati, F.; Prencipe, F.P.; Benvenuti, S. Headspace solid-phase microextraction-gas chromatography-mass spectrometry characterization of propolis volatile compounds. J. Pharm. Biomed. Anal. 2013, 84, 103-111. [CrossRef]

44. Pino, J.A.; Marbot, R.; Delgado, A.; Zumarraga, C.; Sauri, E. Volatile constituents of propolis from honey bees and stingless bees from Yucatan. J. Essent. Oil Res. 2006, 18, 53-56. [CrossRef]

(C) 2020 by the authors. Licensee MDPI, Basel, Switzerland. This article is an open access article distributed under the terms and conditions of the Creative Commons Attribution (CC BY) license (http://creativecommons.org/licenses/by/4.0/). 